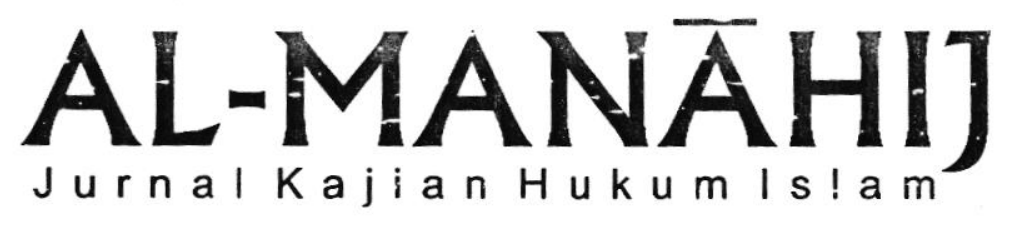




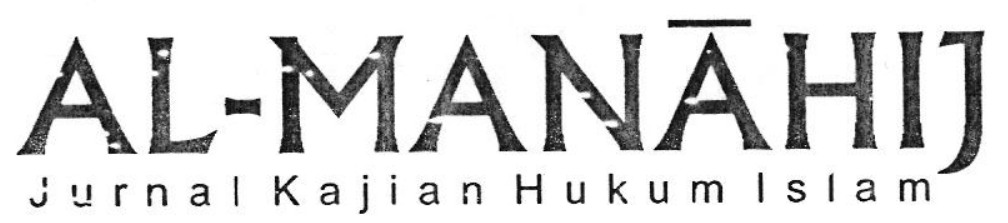

$\begin{array}{lll}\begin{array}{l}\text { Ketua Penyunting } \\ \text { Sekretaris Penyunting }\end{array} & : \text { Jamal Abdul Aziz } \\ \text { Anggota Penyunting } & : \text { H.M. Daelikhin } \\ & \begin{array}{l}\text { Ansori } \\ \text { A. Luthfi Hamidi } \\ \text { Ridwan } \\ \text { Suraji } \\ \text { Endang Widuri }\end{array} \\ & \begin{array}{l}\text { Supriyanto } \\ \text { Rina Heriyanti }\end{array} \\ \text { Editor Bahasa } & \begin{array}{l}\text { Siti Faizah Hidayati } \\ \text { Dyah Ratri Fiyani }\end{array}\end{array}$

\author{
Penerbit \\ Jurusan Syariah STAIN Purwokerto \\ Frekuensi Terbit \\ Duakalisetahun
}

Alamat Redaksi

Jurusan Syari'ah STAIN Purwokerto

J1. Jend. Ahmad Yani 40A Purwokerto 53126

Telp. (0281)635624 Fax. (0281)636553

Email: mal_dulaziz@yahoo.co.id

Al-Manähij adalah jurnal ilmiah Jurusan Syariah STAIN Purwokerto yang terbit dua kali dalam setahun. Jurnal ini memfokuskan pada kajian hukum Islam dalam berbagai sudut pandang keilmuan. Redaksi mengundang para ahli dan segenap civitas akademika untuk menulis artikel sesuai dengan tema besar jurnal ini. Artikel yang dimuat tidak selalu mencerminkam pandangan redaksi ataupun institusi lain yang terkait dengan penerbitan jurnal ini. 


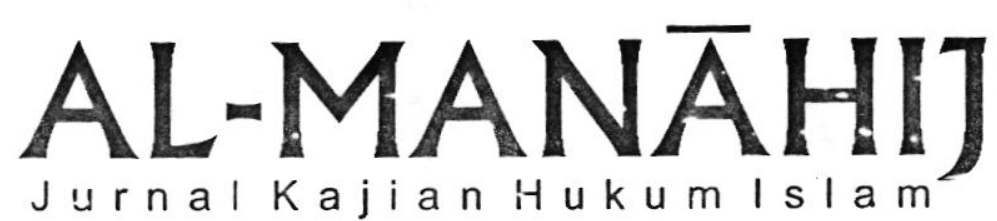

KONSEP NUSYUZ DALAM MAZHAB SYAFI'I

PERSPEKTIF KEADILAN GENDER

Dwi Meitayani 1

GRASI DALAM PERSPEKTIF HUKUM ISLAM

DAN HUKUM POSITIF INDONESIA

Imdadurrouf 23

GOOD GOVERNANCE DALAM PERSPEKTIF

HUKUM ISLAM

Arief Aulia Rachman 41

PELANGGARAN HAK KEKAYAAN INTELEKTUAL

DALAM PERSPEKTIF HUKUM ISLAM

Imam Mustofa 53

PORNOGRAFI DALAM PERSPEKTIF HUKUM ISLAM

DAN HUKUM POSITIF

Vivi Ariyanti 71

MENYOAL HUKUM MEROKOK

DALAM PERSPEKTIF HUKUM ISLAM

Muh. Mukri 91

MENUJU PENEGAKAN HUKUM

YANG LEBIH BERKEADILAN DAN RESPONSIF

Mub. Bachrul Ulum 113 


\title{
GRASI DALAM PERSPEKTIF HUKUM ISLAM DAN HUKUM POSITIF INDONESIA
}

\author{
Imdadurrouf*
}

\section{Abstract}

As one of the right owned by president, grasi is controlled by UUD 1945. In islamic law there is also a possibility to forgive one's mistake in the name of justice and truthfull.

Kata kunci: Grasi, Incrabt, al-Syafá'ab, al-'afuu.

\section{A. Pendahuluan}

Negara Republik Indonesia merupakan negara yang berdasarkan atas hukum. Undang-undang Dasar 1945 menetapakan bahwa Negara Republik Indonesia adalah negara hukum (rechtstaat) sebagaimana dibuktikan dalam Pembukaan, Batang tubuh, dan Penjelasan Undang-Undang Dasar 1945. Termasuk dalam hal ini adalah pemberian grasi oleh presiden, yang pengaturannya tercantum dalam pasal 14 ayat I UUD 1945 yang berbunyi "Presiden memberi grasi dan rehabilitasi dengan memperhatikan pertimbangan Mabkamah Agung". ${ }^{1}$ Sedangkan aturan yuridis teknis tentang grasi secara komprehensif diatur dalam Undang-Undang No.22 tahun 2002 tentang grasi.

\footnotetext{
- Penulis adalah Alumni STAIN Purwokerto Jurusan Syari'ah Program Studi Ahwal al-Syakhsiyyah tahun 2009

${ }^{1}$ Redaksi Sinar Grafika, UUD 1945 Hasil Amandemen \& Proses Amandemen Secara Lengleap (Jakarta: Sinar Grafika, 2008), hal. 10.
} 
Dengan mengajukan grasi kepada presiden, pemohon berharap untuk memperoleh suatu penghapusan, pengurangan pidana ataupun perubahan pidana yang telah ditetapkan oleh pengadilan yang telah incracht van gewijzd (berkekuatan bukum tetap). Permohonan ini tentunya tidaklah mudah dikabulkan presiden, karena proses permohonan yang memakan waktu lama dan selain itu juga presiden mendengarkan pertimbangkan dan masukan dari Mahkamah Agung sebagai pimpinan yudisial tingkat akhir. Jika permohonanya terpenuhi, maka akan di kabulkan permohonan grasi tersebut yaitu dalam bentuk pengapusan atau pengurangan pidana atau perubahan dari pidana yang telah dijatuhkan oleh pengadilan.

Berbeda dengan Hukum Islam yang dianggap oleh sebagian kalangan tidak memiliki suatu konsep "pengampunan" terhadap pelaku pidana, karena acap kali Hukum Islam lebih terdengar sebagai hukum yang kejam, karena memberlakukan pola eksekusi hukuman dengan potong tangan, cambuk, rajam dan hukuman lain yang mereka pandang sebagai tindakan yang tidak manusiawi dan melanggar hak asasi manusia.

Argumen-argumen di atas, khususnya mengenai hukum pidana Islam, lahir bukan karena sikap antagonisme terhadap Islam tetapi lebih karena ketidakmengertian atau kecurigaan terhadap hukum Islam itu sendiri. Karena Dalam hukum Islam telah banyak pembahasan mengenai bagaimanakah ketika seseorang itu melakukan suatu perbuatan tindak pidana atau jarimah dan bagaimana pula bentuk tindakan penguasa atau korban dalam Islam ketika terjadi suatu pelanggaran atau kejahatan yang menimpa terhadap seseorang. ${ }^{2}$

Dalam hal ini, maka Hukum Islam juga memberikan adanya suatu pengampunan kepada para pelaku jarimah atau pelaku tindak pidana. Praktik pengampunan tersebut telah ada pada pada masamasa sejarah Islam yang telah lampau. Dalam kajian Hukum Islam, istilah grasi tidaklah diketemukan. Tetapi di dalam Fiqh Jināyah

${ }^{2}$ Abul A'lā al-Mawdūdi, Islamic Lav and Constitution (Karachi: Jamaat e Islami Publication, 1995), hal. 13. 
terdapat suatu ketentuan istilah yang memiliki suatu pengertian yang idektik dengan istilah grasi yaitu al-Shafa'b dan al-'afwu. Istilah ini merujuk dengan menyandarkannya kepada nash maupun di dalam hadis Nabi.

Pembahasan mengenai Grasi adalah merupakan suatu hal yang menarik untuk di kaji baik dari sisi Hukum positif maupun dari sisi Hukum Islam. Karena seseorang yang telah dijatuhi hukuman pemidanaan oleh pengadilan dan telah incracht, dapat terhapus atau berubah pemidanaannya dari yang telah ditetapkan. Dalam sisi Hukum Islam apakah tujuan dari maqäsid al-sharì'ab dapat tercapai, karena terhapus atau berubahnya pemidanaan yang bersifat tetap karena mengajukan grasi. Dalam tulisan ini penulis berusaha untuk mengkajinya melalui suatu telaah dalam suatu perspektif Hukum Islam.

\section{B. Pengertian Grasi}

Perkataan grasi berasal dari bahasa latin "gracia" yang berarti ampun, pengampunan. ${ }^{3}$ Bagirmanan, dalam bukunya Lembaga Kepresidenan, mengartikan bahwa grasi adalah kewenangan Presiden memberi pengampunan dengan cara meniadakan, mengubah atau mengurangi pidana bagi seorang yang dijatuhi pidana dan telah memperoleh kekuatan hukum tetap. ${ }^{4}$ Sedangkan menurut Van Hamel sebagaimana dikutip oleh P.A.F Lamintang dalam bukunya Hukum Penitensier, menjelaskan bahwa beliau merumuskan apa yang beliau sebut sebagai gratieverlening atau pemberian grasi sebagai: "Een verklaring van bet souvereine gezag, dat de strafrechtelijke gevolgen van een delikt geheel of ten deele worden opgeheven", yang artinya : "Suatu pernyataan dari kekuasaan yang tertinggi yang menyatakan bahwa akibat-akibat menurut hukum pidana dari suatu delik itu menjadi ditiadakan, baik seluruhnya maupun untuk sebagian". ${ }^{5}$

${ }^{3}$ Andi Hamzah dan Irdan Dahlan, Upaya Hukum Dalam Perkara Pidana, cet. I (Jakarta: PT Bina Aksara, 1987), hal. 134.

${ }^{4}$ Bagirmanan, Lembaga Kepresidenan, cet. 3 (Yogyakarta: FH UII Press, 2006), hal. 158.

${ }^{5}$ P.A.F. Lamintang, Hukum Panitensier (Bandung: CV. Armico, 1984), hal. 282. 
Pemberian grasi atau pengampunan pada mulanya dizaman kerajaan absolut di Eropa adalah berupa anugerah raja (vorstelijk guns) yang memberikan pengampunan kepada orang yang telah dipidana, jadi sifatnya sebagai kemurahan hati raja yang berkuasa. Tetapi setelah tumbuhnya negara-negara modern di mana kekuasaan kehakiman telah terpisah dengan kekuasaan pemerintahan atas pengaruh dari paham Trias politica, yang mana kekuasaan pemerintahan tidak dapat sekehendaknya ikut campur kedalam kekuasaan kehakiman, maka pemberian grasi berubah sifatnya, menjadi sebagai upaya koreksi terhadap putusan pengadilan, khususnya dalam hal mengenai pelaksanaannya. $^{6}$

\section{Pidana yang dapat Dimohonkan Grasi}

Secara istilah "pidana" didefinisikan sebagai suatu penderitaan yang sengaja dijatuhkan atau diberikan oleh negara pada seseorang atau beberapa orang sebagai akibat hukum (sanksi) baginya atas perbuatannya yang telah melanggar larangan hukum pidana. Wujud penderitaan yang dapat dijatuhkan oleh negara itu telah ditetapkan dan diatur secara rinci, baik mengenai batas-batas dan cara menjatuhkannya serta di mana dan bagaimana cara menjalankannya. ${ }^{7}$

Mengenai wujud jenis penderitaan itu, tercantum di dalam pasal 10 KUHP. Tetapi wujud batas dan berat ringannya dalam menjatuhkannya dimuat dalam rumusan mengenai masing-masing larangan dalam hukum pidana yang bersangkutan. Jadi, negara tidak bebas untuk memilih sekehendaknya dari jenis-jenis pidana dalam pasal 10 KUHP tadi. Hal ini berkaitan dengan fungsi hukum pidana sebagai membatasi kekuasaan negara dalam arti memberi perlindungan hukum bagi warga negara dari tindakan negara dalam rangka negara menjalankan fungsi menegakan hukum pidana. ${ }^{8}$

\footnotetext{
${ }^{6}$ Adami Chazawi, Pelajaran Hukum Pidana Bagian 2 Jakarta: PT RajaGrafindo Persada, 2002), hal. 190.

7 Adami Chazawi, Pelajaran Hukum Pidana Bagian 1 Jakarta: RajaGrafindo Persada, 2002), hal. 24.

${ }^{8}$ Aruan Sakijo, Hukum Pidana: Dasar Aturan Umum Hukum Pidana Kodifikasi (Jakarta: Ghalia Indonesia, 1990), hal. 89.
} 
Pemidanaan dalam hukum pidana adalah suatu alat dan bukan tujuan dari hukum pidana, yang apabila dilaksanakan tiada lain adalah berupa penderitaan atau rasa tidak enak bagi yang bersangkutan yaitu yang disebut dengan terpidana. Tujuan utama hukum pidana adalah ketertiban, yang secara khusus dapat disebut terhindarnya masyara'kat dari perkosaan-perkosaan terhadap kepentingan hukum yang dilindungi, selain itu juga bertujuan sebagai pencegahan (preventif) bagi setiap orang yang berniat untuk melanggar hukum pidana, ${ }^{9}$ sehingga dengan demikian masyarakat akan merasa tentram dan terlindungi.

Berdasarkan ketentuan yang terdapat dalam pasal $10 \mathrm{Kitab}$ Undang-Undang Hukum Pidana, terdapat dua hukuman yang diterapkan dalam hukum positif di Indonesia yaitu hukuman pokok dan hukuman tambahan. Hukuman pokok terdiri dari pidana mati, pidana penjara, pidana kurungan, pidana denda. Hukuman tambahan terdiri dari pencabutan hak-hak tertentu, perampasan barang-barang tertentu, dan pengumuman putusan hakim. ${ }^{10}$

Dari ketentuan pidana tersebut di atas, maka apabila suatu putusan telah diputuskan oleh hakim dan telah mempunyai kekuatan hukum yang tetap (inkracht van gewijsd), maka hanyalah terhadap pidana mati dan pidana penjara yang hanya dapat diajukan permohonan grasinya kepada Presiden, hal ini berdasarkan pada ketentuan Undang-Undang No. 22 tahun 2002 tentang grasi yaitu pada pasal 2 ayat 2 menyebutkan bahwa:

'Putusan pemidanaan yang dapat dimobonkan grasi sebagaimana dimaksud pada ayat 1 adalah pidana mati, penjara seumur bidup, dan penjara paling rendab 2 (dua) tabun.',1

Berdasarkan ketentuan pasal di atas, maka seseorang yang dijatuhi hukuman pokok kurungan dan denda tidaklah dapat

\footnotetext{
9 Adami Chazawi, Pelajaran., hal. 25.

${ }^{10}$ Leden Marpaung, Asas Teori Praktek Hukum Pidana, cet. 4 Jakarta: Sinar grafika, 2008), hal. 108.

${ }^{11}$ Varia Peradilan, Undang-Undang No. 22 Tabun 2002 Tentang Grasi, hal. 11.
} 
mengajukan grasinya ke Presiden. Karena persyaratan permohonannya menurut ketentuan Pasal 2 ayat 2 tidak terpenuhi, karena hukuman maksimum kurungan adalah satu tahun. Selain itu untuk hukuman tambahan juga demikian, karena sifatnya hukuman tambahan yang hanya dapat dijatuhkan bersama-sama dengan hukuman pokok, sehingga ketentuan hukuman tambahan ini tidak dapat dimohonkan grasi kepada Presiden.

\section{Grasi dalam Hukum Islam}

Dalam kajian fiqh jināyah, tidak temukan istilah grasi tetapi dapat diketemukan istilah as-Syafá'ab dan al-'afwu. Lafadz "Syafa" menurut arti semula adalah tiap-tiap satuan yang genap. Akan tetapi kemudian arti itu berkembang menjadi "Suatupermobonan dari seseorang terbadap orang lain agar dipenubi keinginannya." Diartikan demikian karena orang yang meminta pertolongan itu bagaikan orang yang menyendiri yang memerlukan pertolongan kepada orang lain. Dia baru dikatakan tidak sendiri apabila telah berhubungan dengan orang yang dimintai al-Shafa' ab. ${ }^{12}$ 'Ali ibn Muhammad ibn 'Ali al-Jurjāni, seorang ahli ilmu kalam dan ahli hukum, memberikan definisi al-Shafa'ab sebagai:



Sedangkan istilah al-'afwu menurut 'Abd al-Qadir 'Audah dalam kitabnya al-Tashrì' al-Jinā'i al-Istamì

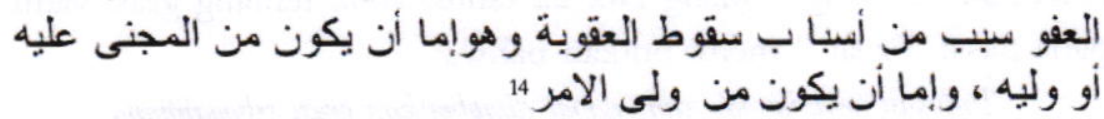

Pengampunan dalam Fiqh Jināyah memiliki pertimbangan yang tergantung pada jenis pelanggaran pidana yang dilakukan. Berikut ini dikemukanakan jenis-jenis pidana dalam Islam serta hukum yang memberikan pengampunan terhadap pelaku pidana tersebut:

${ }^{12}$ Fatchur Rahman, Hadis-Hadis Tentang Peradilan Agama Jakarta: Bulan Bintang, 1977), hal. 234.

${ }_{13}$ 'Ali ibn Muhammad ibn 'Ali al-Jurjânî, al-Ta'îfât, (Beirut: Dār al-Kitāb al-Arabî, t.t), I: 41.

14 'Abd al-Qadir 'Awdah, al-Tasyñ' al-Jināî̀ al-Islamî, (Beirut: Mu'assasah al-Risālah, 1996), I: 774. 


\section{Jarimah Hudūd}

Jarimah hudüd adalah jarimah yang diancam dengan hukuman bad. ${ }^{15}$ Pengertian hukuman had, sebagaimana dikemukakan oleh 'Abd al-Qadir 'Audah adalah:

\section{و الحد هو العقو بة المقت رة حق ا لله نعالىى}

Jarimah budūd adalah suatu jarimah yang bentuknya telah ditentukan syara' sehingga terbatas jumlahnya. Selain ditentukan bentuknya (jumlahnya), juga ditentukan hukumannya secara jelas, baik melalui al-Quran maupun al-Hadis. ${ }^{17}$ Adapun jarimab yang termasuk dalam kelompok ḅudüd ada tujuh macam yaitu: ${ }^{18}$ berzina, menuduh orang berzina (qadzaf), meminum minuman keras, pencurian, pembegalan, keluar dari agama Islam (murtad) dan pemberontakan.

Pada jarimah b̧udūd ini tidak ada pengampunan sama sekali, baik dari si korban atau dari penguasa tertinggi (kepala negara). Pengampunan dari salah satunya tidak mempengaruhi kepada ke jarimahan perbuatan yang dilakukan ataupun hukumannya. ${ }^{19}$ Hal ini ditegaskan dengan hadis dari Ibnu Umar:



Dalam sebuah hadis yang diriwayatkan oleh Aisyah r.a juga ditegaskan:

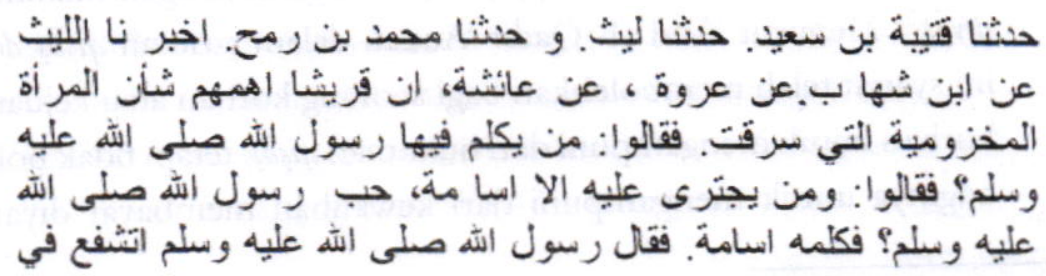

\footnotetext{
${ }^{15}$ Ahmad Wardi Muslich, Hukum Pidana Islam (Jakarta: Sinar Grafika, 2005), hal. x.

16 'Awdah, al-Tasyrì',, hal. 79.

${ }^{17}$ Rahmat Hakim, Hukum Pidana Islam (Bandung: Pustaka Setia, 2000), hal. 26-27.

18 'Awdah, al-Tasyri', hal. 79.

${ }^{19}$ Ahmad Hanafi, Asas-Asas Hukum Pidana Islam (Jakarta: Bulan Bintang, 1981), hal. 18.

${ }^{20}$ Muḥammad ibn Afi ibn Muḥammad al-Shawkāni, Nayl al-Awțär Sharh Muntaqā al-
} Akebbär, Juz VI, hal. 120. 


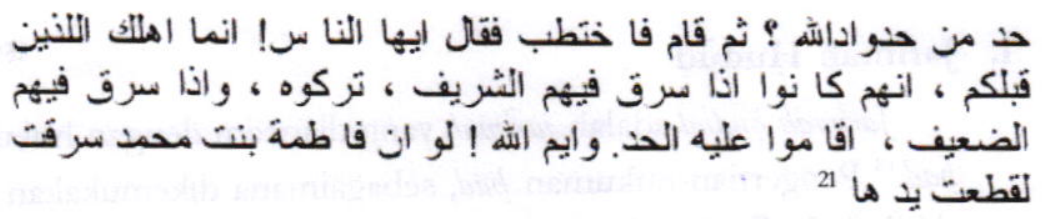

\section{Jarimah Qisòāsò Diyāt}

Qisòāsò adalah pelaksanaan hukuman dengan cara sebagaimana pelaku pidana melaksanakan perbuatan yang mengakibatkan orang lain wafat atau luka, ${ }^{22}$ sedangkan diyat merupakan hukuman pengganti dari hukuman qiṣaș yang dimaafkan. ${ }^{23}$ Jarimah yang termasuk dalam kelompok jarimah qișạs diyat ini terdiri atas lima macam yaitu: ${ }^{24}$

a. Dua jarimah masuk dalam kelompok jarimah qisoaso yaitu:

i. القتل العدد (Pembunuhan sengaja)

ii. الجنا بة على ما دون النفس عمدا (Penganiayaan sengaja)

b. Kemudian tiga jarimah masuk dalam kelompok diyat yaitu:
i. القتل شبه العمد (Pembunuhan menyerupai sengaja)
ii. القتل الخطا (Pembunuhan karena kesalahan)
iii. الجنا بِة على ما دون النفس خطأ (Penganiayaan tidak sengaja)

Dalam jarimah qișâs diyät ini, pengampunan hanya bisa diberikan oleh si korban atau keluarganya. Pengampunan yang diberikannya mempunyai pengaruh dan oleh karena itu si korban bisa memaafkan hukuman qișass, untuk diganti dengan hukuman diyät. ${ }^{25}$ Menurut 'Abd al- Qadir 'Audah dalam jarimah qișạs diyat ini syariat telah membolehkan bagi seorang korban atau keluarga korban untuk mengampuni dari hukuman qișass, tetapi tidak boleh baginya untuk mengampuni dari kewajiban membayar diyat. ${ }^{26}$

${ }^{21}$ Imām Abū Zakariya ibn Sharaf al-Nawawìn, Șaf̧iţ Muslim, (ttp: Där al-Fikr, tt),XI: 155.

${ }^{22}$ Abu Yazid (ed.), Figh Realitas Respon Ma'bad Aby Terbadap Wacana Hukum Islam Kontemporer (Yogyakarta: Pustaka Pelajar, 2005), hal. 39.

${ }^{23}$ Rahmat Hakim, Hukum., hal. 29.

24 'Awdah, al-Tashri'., hal.79.

${ }^{25}$ Hanafi, Asas, hal. 18.

26 'Awdah, al-Tashri'., hal.775. 
Sehingga diyāt sebagai wujud ganti rugi bagi korban karena pembuat jarimah mendapatkan pemaafan dari korban atau keluarganya. Dengan demikian si pelaku jarimah harus memberikan sejumlah harta kepada si korban atau keluarga korban, dengan besar kecilnya menurut jenis jarimah yang diperbuat. ${ }^{27}$

Kepala negara dalam kedudukannya sebagai penguasa tertinggi, tidak boleh memberikan pengampunan dalam jarimah qișaṣ diyāt karena hanya dimiliki oleh korban atau keluarga korban. ${ }^{28}$ Akan tetapi kalau korban tidak cakap (masih di bawah umur atau tidak waras), sementara dia tidak memiliki wali, maka kepala negara bisa menjadi walinya. ${ }^{29}$ Jadi kedudukannya sebagai wali itulah yang memungkinkan dia memberikan pengampunan, hal ini ditegaskan dalam sebuah kaidah dalam Islam bahwa penguasa menjadi wali bagi orang yang tidak mempunyai wali: ${ }^{30}$



Menurut Imām Mālik sebagaimana dikutip oleh 'Abd al-Qadir 'Awdah dalam kitabnya al-Tashri' al-Jināi al-Islami orang yang berhak mengampuni adalah orang yang berhak menuntut qisăs, yaitu ahli waris 'așabah yang lebih dekat derajatnya dengan si korban, ahli waris perempuan yang derajatnya tidak sama dengan ashabah dan orang perempuan sekiranya ia bersama-sama dengan orang laki-laki yang sederajat ia menjadi ahli waris ashabah (bil ghair). Mereka ini harus memenuhi syara't, yakni telah dewasa dan berakal sehat. ${ }^{31}$

Sedangkan menurut Imām Abū Hanifah, Imām asy-Syāifī dan Imām A ḥmad menjelaskan bahwa orang-orang yang berhak

${ }^{27}$ Hakim, Hukum, hal. 29.

28 'Abdurrahmān al-Māliki, Sistem Sanksi Dalam Islam, terj. Syamsuddin Ramadlan. (Bogor: Pustaka Thariqul Izzah, 2002), hal. 320.

${ }^{29}$ Hakim, Hukum, hal. 28.

${ }^{30} \mathrm{Abu}$ 'Abd Allāh Aḥmad ibn Muḥammad ibn Ḥanbal ibn Hilāl ibn Asad al-Shaybān̄, Musnad al-Imäm Aḅmad ibn Hanbal, taḥ̣iqq: al-Sayyid Abū al-Mu’ạ̣i al-Nüri, cet. 1 (Beirut: 'Alam al-Kutub, 1998), VI: 165.

31 'Awdah, al-Tasyñ'., hal. 159. 
menuntut qisòasò dan sekaligus berhak memberikan pengampunan adalah semua ahli waris dari golongan keturunan dan ahli waris sababiyah, baik laki-laki maupun perempuan, dengan syarat apabila telah dewasa dan sehat pikirannya. ${ }^{32}$

Dasar hukum di perbolehkan memberikan pengampunan kepada orang yang melakukan pembunuhan diantaranya adalah terdapat dalam firman Allah dalam Surat al-Baqarah: 178

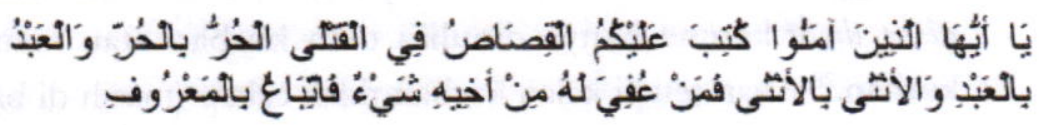

Menurut M. Quraish Shihab dalam Tafsir al-Mișbāh, kata qișās menganrung arti "persamaan", boleh menuntut lelaki walau ia membunuh wanita, demikian juga sebaliknya, karena itulah keadilan dan persamaan dalam mencabut nyawa seorang manusia. Kemudian dalam kalimat ( فمن عفي له ) menegaskan bahwa jika keluarga teraniaya ingin memaafkan dengan menggugurkan sanksi itu dan menggantinya dengan tebusan, maka hal itu dapat dibenarkan. Disini terlihat bahwa agama tidak memaksakan pemaafan, karena pemaafan yang dipaksakan akan berdampak buruk. Keluarga yang ingin memaafkan dengan pertimbangan apapun dapat dibenarkan bahkan terpuji. ${ }^{33}$

Kemudian Sumber hadisnya adalah sabda Rasulullah SAW yang diriwayatkan oleh Anas r.a yang mengatakan:

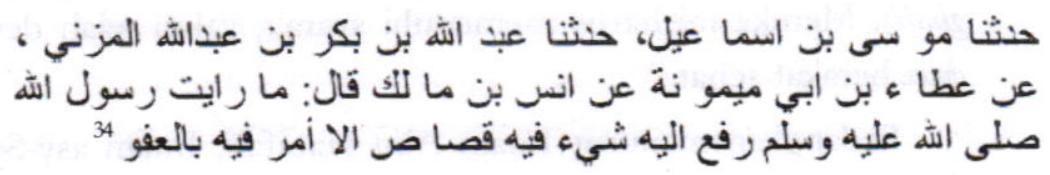

Dasar hukum tersebut di atas adalah dalil yang menunjukan bahwa anak adam berhak memberikan pengampunan dalam masalah qișạs diyät. Jadi dapatlah disimpulkan bahwa pengam-

\footnotetext{
${ }^{32}$ Rahman, Hadis., hal. 242.

${ }^{33}$ M. Quraish Shihab, Tafsîr al-Mîsbâh, (Jakarta: Lentera Hati, 2000), I: 368.

${ }^{34} \mathrm{Abū}$ Dāurud Sulaymān ibn al-Asy'ath as-Sijistānî, Sunan Abī Dänud, (Dār al-Fikr:
} Libanon, 1994), II: 370. 
punan dalam perkara qișaș diyāt hanya dibolehkan dari pihak korban atau keluarga korban saja.

\section{Jarimah Ta'zir}

Jarimah Ta'zir adalah jarimah yang diancam dengan hukuman ta'zir Pengertian $t a$ '₹ $\bar{i}$ ir menurut bahasa adalah $t a{ }^{\prime} \bar{i} b$, artinya memberi pelajaran. ${ }^{35}$ Sedangkan pengertian $t a^{\prime}$ 'zir menurut istilah, sebagaimana dikemukakan oleh al-Māwardi adalah:



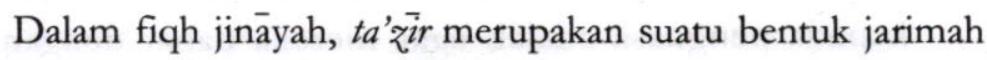
yang bentuk atau macam jarimah serta hukuman (sanksi) jarimah ini di tentukan penguasa. ${ }^{37} \mathrm{Jadi}$, jarimah ini sangat berbeda dengan jarimah b̧udūd dan qișaș atau diyät yang macam dan bentuk hukumannya telah ditentukan oleh syara', sebab jarimah ini berkaitan dengan perkembangan masyara'kat serta kemaslahatannya. Kemaslahatan selalu berubah dan berkembang dari satu waktu ke lain waktu dan dari satu tempat ke tempat lain. Oleh karena itu, sesuatu dapat dianggap kemaslahatan pada suatu masa, bisa jadi tidak lagi demikian pada waktu yang lain. Demikian pula, sesuatu itu dapat dianggap maslahat disuatu tempat, ada kemungkinannya tidak demikian di tempat lain. ${ }^{38}$

Jarimah $t a$ 'zir tidak berbilang dan tidak mungkin terbilang. Hal ini karena disamping banyaknya, juga mungkin terjadi fluktuasi, perubahan waktu dan tempat sesuai dengan kemaslahaatannya. Namun demikian, syara' menyebutkan sebagian kecil dari jarimah dan berlaku untuk seluruh tempat tanpa penge-


dan tidak akan terjadi perubahan terhadapnya, artinya pebuatanperbuatan itu akan dianggap selamanya sebagai jarimah. Jarimah

35 'Awdah, al-Tasyri'., hal. 80.

${ }^{36}$ Abū al- Hasan al-Māwardi, al-Ableām as-Suṭāniyah, cet. III (Beirut: Dār al-Fikr, 1975), hal. 236.

37 'Awdah, al-Tasyri'., hal. 776.

${ }^{38}$ Hakim, Hukum., hal. 31. 
ta'zir yang ditentukan syara" di antaranya adalah khianat, suap menyuap, ingkar janji, riba, berjudi dan sebagainya. Namun

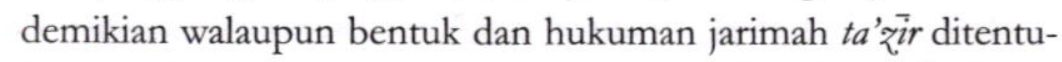
kan syara", penerapan sanksinya diserahkan kepada kebijaksanan hakim. Dia dapat memilih rangkaian hukuman dari yang seringan ringannya sampai seberat beratnya. Hal ini karena pada dasarnya jarimah ini adalah hak penguasa. ${ }^{39}$

Dalam jarimah $t a$ 'থir, penguasa dimungkinkan untuk memberikan pengampunan kepada jāni (pelaku tindak kriminal). ${ }^{40}$ Pemberian kekuasaaan dalam menentukan bentuk jarimah ini kepada penguasa adalah agar mereka dapat dengan leluasa mengatur pemerintahannya sesuai dengan situasi dan kondisi wilayahnya, serta kemaslahatan daerahnya. ${ }^{41}$ Menurut pendapat fuqahā' sebagaimana dikutip oleh 'Abd al-Qadir 'Audah, menegaskan bahwa bagi pemegang perkara (ulil amr) memiliki hak mengampuni dalam jarimah $t a^{\prime} z^{i r}$ dari hukuman atau sebagian hukuman yang telah ditetapkan. ${ }^{42}$ Yaitu jika ta'zir yang dilakukannya adalah memiliki bobot ringan, tetapi jika memiliki bobot yang berat, maka hukuman harus dilaksanakan.

\section{E. Kedudukan Grasi dalam Perspektif Hukum Islam}

Kedudukan grasi jika di tilik dari sisi permohonannya, grasi di Indonesia dimohonkan kepada Presiden sebagai kepala negara, sedangkan dalam Hukum Islam permohonaan tersebut diajukan kepada Khalifah atau penguasa Islam yang sedang berkuasa. Sedangkan dari sisi substantif permohonanya yaitu adanya suatu permohonan pengampuanan dari seseorang yag dijatuhi pidana kepada penguasa untuk memperoleh suatu pengampuanan, yang wujudnya dapat berupa penghapusan, pengurangan atau perubahan jenis pidana yang telah dijatuhkan guna memperoleh suatu pidana yang lebih ringan dari yang telah ditetapkan.

\footnotetext{
${ }^{39}$ Ibid., hal. 32.

40 'Awdah, al-Tasyrī'., hal. 81.

${ }^{41}$ Hakim, Hukum., hal. 31.

42 'Awdah, al-Tasyrī'., hal. 776.
} 
Ketentuan grasi di Indonesia memberikan syara' bahwa pidana yang dapat dimohonkan grasinya kepada Presiden hanyalah pidana mati, pidana penjara seumur hidup dan penjara minimal dua tahun (Undang-Undang No. 22 tahun 2002 pasal pasal 2 ayat 2). Ketentuan ini jika ditilik secara komprehensif belumlah memberikan rasa keadilan, karena memiliki keterbatasan terhadap batasan hukuman minimal, yang dapat dimohonkan grasinya kepada Presiden. Sehingga terhadap pelaku pidana yang dijatuhi pidana dibawah dua tahun secara otomatis tidak dapat mengajukan permohonannya kepada Presiden. Sedangkan dalam konsep Hukum Islam sendiri permohonan pengampunan tidak di bagi kedalam jumlah minimal dan maksimal, tetapi lebih melihat pada persoalan tindak pidana atau macam jarimah yang dilanggar, yaitu apakah jarimah budūd, jarimah qisòäsò diyât atau ta'zîr.

Dalam Hukum Islam, pengampunan diberikan karena pertimbangan aspek kemaslahatan, sehingga Khalifah atau penguasa Islam dalam mempertimbangkannya menggunakan dasar hukum nash dan hadis yang telah ditetapkan dan juga hukum yang berkembang di dalam masyara'kat.

Dalam hal pembunuhan terhadap jiwa yang dilarang dan terhadap penganiayaan, ketentuan hukum positif di Indonesia menyatakan bahwa ketika perbuatan tersebut telah terbukti dan telah ditetapkan hukuman oleh pengadilan, maka pelaku tindak pidana tersebut dapat mengajukan permohonan grasi kepada Presiden. Selain itu pula hukuman terebut juga memenuhi syara't untuk diajukan grasi kepada Presiden, yaitu minimal dua tahun dan maksimal hukuman mati (Pasal 2 ayat 2 Undang-Undang No. 22 tahun 2002). Selain itu juga keputusan pemidanaannya telah memiliki kekuaatan hukum yang tetap dan terpidana juga telah mengakui perbuatannya tersebut.

Presiden diberikan hak dan kewenangan untuk dapat mengabulkan atau menolak permohonannya, tentunya setelah memperhatikan pertimbangan dari Mahkamah Agung. Ketentuan inilah yang membedakannya dengan Hukum Islam, karena dalam ketentuan Hukum Islam kewenangan tersebut tidak berada pada hak kepala 
Negara, tetapi pada korban atau keluarga korban. Disinilah letak keadilan dalam Hukum Islam, karena dalam perkara ini hak sesama manusia lebih dominan. Jika korban atau keluarga korban mengampuninya, maka pelaku tidak terbebas begitu saja, tetapi hak diyat tetap menjadi pengganti dari dihapuskannya hukuman qisòasò tersebut. Hal inilah yang dipaparkan oleh 'Abd al-Qadir 'Awdah yang menyatakan bahwa dalam jarimah qisòasò diyat, syariat telah membolehkan bagi korban atau keluarga korban untuk mengampuni dari hukuman qisòasò tetapi tidak boleh baginya untuk mengampuni dari kewajiban membayar diyat. ${ }^{43}$ Diyät sebagai wujud ganti rugi bagi korban karena pembuat jarimah mendapatkan pemaafan dari korban atau keluarganya. Dengan demikian si pelaku jarimah harus memberikan sejumlah harta kepada si korban atau keluarga korban, dengan besar kecilnya menurut jenis jarimah yang diperbuat. ${ }^{44}$

Begitu pula halnya dalam jarimah $t a '{ }^{\prime}{ }^{i}$, Khalifah atau penguasa Islam diberikan kewenangan penuh untuk mengatur dalam wilayah hukumnya serta menjatuhkan pidana sesuai dengan aturan dan ketetapan yang berlaku. Dan dalam jarimah ta'zír ini, penguasa juga dimungkinkan untuk dapat memberikan pengampunan kepada jäi (pelaku tindak kriminal). ${ }^{45}$ Pemberian kekuasaaan dalam menentukan bentuk jarimah ini kepada penguasa adalah agar mereka dapat dengan leluasa mengatur pemerintahannya sesuai dengan situasi dan kondisi wilayahnya, serta kemaslahatan daerahnya. ${ }^{46}$ Sehingga penetapan sanksinya diserahkan kepada Khalifah dan beliau juga berhak meringankan hukuman atau memberikan pengampunan. ${ }^{47} \mathrm{Hal}$ ini sebagaimana ditegaskan menurut pendapat fuqoha sebagaimana dikutip oleh 'Abd al-Qadir 'Awdah yang menegaskan bahwa bagi pemegang perkara (ulil amri) memiliki hak mengampuni dalam jarimah ta'zir dari hukuman atau sebagian hukuman yang telah ditetapkan. ${ }^{48}$

\footnotetext{
43 'Awdah, al-Tasyri'., hal.775.

${ }^{44}$ Hakim, Hukum., hal. 29.

45 'Awdah, al-Tasyrī', hal. 81.

${ }^{46}$ Hakim, Hukum., hal. 31.

${ }^{47}$ Al-Mâliki, Nizām al- 'U qübat, hal. 320.

48 'Awdah, al-Tasyri'., hal. 776.
} 
Presiden memiliki hak dalam hal grasi karena memiliki kekuasaan dalam wilayah yudikatif, dan hal ini telah ditentukan oleh UndangUndang Dasar 1945 dalam pasal 14. Dalam Hukum Islam kekuasaan Khalifah dalam wilayah ini adalah merupakan bagian dari salah satu kewenangannya, walaupun terdapat pengeculian terhadap jarimah qisòasò diyat. Karena dalam jarimah ini kewenangan hanyalah menjadi hak dari korban atau keluarga korban untuk menjatuhkan qisòasò atau dapat pula memberikan pengampunan kepada pelakunya, dan tentunya ketika pengampunan diberikan, maka diyat menjadi pengganti dari qisòasò yang terhapuskan.

\section{F. Penutup}

Hukum Islam merupakan peraturan Ilahi yang sempurna. Persoalan-persoalan yang bersifat parsial hanya dapat dimengerti hikmahnya jika dipahami secara menyeluruh berdasar kepada ketentuan-ketentuan, prinsip-prinsip dan kandungan yang dikaji secara komprehensif.

Dari pembahasan tersebut, grasi di Indonesia hanya dapat dimohonkan kepada Presiden terhadap semua jenis pemidanaan dengan ancaman hukuman minimal adalah dua tahun, sedangkan dalam ketentuan Hukum Islam pemberian pengampunan tersebut hanya dimungkinkan terhadap Jarimah $t a$ '₹ir yaitu kepada Khalifah atau penguasa Islam, sedangkan dalam Jarimah qisòàsò diyāt pertimbangan pengampunan bukan kepada Khalifah atau penguasa Islam melainkan kepada korban atau keluarga korban. Tetapi jika dalam Jarimah ḅudūd pengampunan ini tidak berlaku baik oleh penguasa Islam ataupun pihak korbannya, karena jarimah budūd merupakan hak mutlak kekuasaan dari Allāh SWT, dan bersifat tetap (qat'ı) ketentuannya. 


\section{DAFTAR PUSTAKA}

Andi Hamzah dan Irdan Dahlan. Upaya Hukum Dalam Perkara Pidana. Jakarta: P.T. Bina Aksara, 1987.

Arifin, Bey, dkk. Terjemah Sunan Abî Dâwud, 6 jilid. Semarang: CV Asy Syifa, 1993.

'Awdah, 'Abd al- Qadir. Al-Tashrī' al-Jināīi al-Islami, 2 juz. Beirut: Mu `assasah al-Risālah, 1996.

Bagirmanan. Lembaga Kepresidenan. Yogyakarta: FH UII Press, 2006. Chazawi, Adami. Pelajaran Hukum Pidana Bagian 1. Jakarta: RajaGrafindo Persada, 2002.

_- _ Pelajaran Hukum Pidana Bagian 2. Jakarta: PT RajaGrafindo Persada, 2002.

Hakim, Rahmat. Hukum Pidana Islam (Figh Jināalab). Bandung: Pustaka Setia, 2000.

Hanafi, Ahmad. Asas-Asas Hukum Pidana Islam.. Jakarta: Bulan Bintang, 19

Al-Jurjāni, 'Ali ibn Muhammad ibn 'Ali. Al-Ta'rifat, 2 juz. Beirut: Dār al-Kitāb al-'Arabi, t.t.

Lamintang, P.A.F. Hukum Panitensier. Bandung: CV. Armico, 1984. Al-Māliki, 'Abd al-Rahmān. Sistem Sanksi dalam Islam, terj. Syamsuddin Ramadlan. Bogor: Pustaka Thariqul Izzah, 2002.

Marpaung, Leden. Asas Teori Praktek Hukum Pidana. Jakarta: Sinar grafika, 2008.

Al-Māwardi Abū al-Ḥasan. Al-Aḅkām al-Suṭāniyyah. Beirut: Dār alFikr, 1975.

Al-Mawdūdi, Abul A'tā. Islamic Law and Constitution. Karachi: Jamaat e-Islami Publication, 1995. 
Muslich, Ahmad Wardi. Hukum Pidana Islam. Jakarta: Sinar Grafika, 2005.

Al-Nawawi, Imām Abū Zakariya ibn Syarf. Sharḅ Șabih Muslim, 12 juz. Ttp.: Dār al-Fikr, t.t.

Rahman, Fatchur. Hadis-Hadis Tentang Peradilan Agama. Jakarta: Bulan Bintang, 1977.

Razak dan Rais Latief. Terjemah Hadis Shaḅ̂h Muslim, 2 jilid. Jakarta: Pustaka Al-Husna, 1980.Yazid, Abu, (ed.). Fiqh Realitas: Respon Ma'bad Aly Terhadap Wacana Hukum Islam Kontemporer. Yogyakarta: Pustaka Pelajar, 2005.

Sakijo, Aruan. Hukum Pidana: Dasar Aturan Umum Hukum Pidana Kodifikasi. Jakarta: Ghalia Indonesia, 1990.

Al-Shaybāni, Abū 'Abd Allāh Aḥmad ibn Muhammad ibn Hanbal ibn Hilāl ibn Asad. Musnad al-Imām Aḅmad ibn Hanbal, taḥiqu: al-Sayyid Abū al-Mu'âtị al-Nūrì, 6 jilid. Beirut: 'Alam al-Kutub, 1998.

Shihab, M. Quraish. Tafsîr al-Mîsbâh, 15 jilid. Jakarta: Lentera Hati, 2000 .

Al-Sijistāni, Abi Dāwud Sulaimān ibn al-Asy'ace. Sunan Abī Däwud, 6 Juz. Beirut: Dār al-Fikr: 1994.

Redaksi Sinar Grafika. UUD 1945 Hasil Amandemen \& Proses Amandemen Secara Lengkap. Jakarta: Sinar Grafika, 2008. Varia Peradilan, Undang-Undang No. 22 Tabun 2002 Tentang Grasi 
Imdadurrouf 